\title{
Sex Education (or the Lack Thereof) in Kazakhstan: Heteronormative Propaganda in the Curriculum of Özin Özi Tanul Samopoznanie
}

\section{Aizada Arystanbek}

\begin{abstract}
This qualitative study uses interpretive political and discourse analyses methods to examine how the lack of a sex education policy in the educational curriculum in Kazakhstan and the presence of alternative subjects that focus on the 'moral' education of students is connected to the country's nation-building efforts. Using a feminist critique of gendered nationalism and heteronormativity, the text argues that the lack of comprehensive sex education in the country is consistent with the positioning of women as passive subjects whose bodies are weaponised to delineate cultural and national differences of the group. Kazakhstan's authoritarian government uses the subjects özin özi tanu or samopoznanie (knowing oneself) taught in schools to normalise standards of hegemonic femininity and masculinity among youth. The study examines the official school curriculum and state-issued textbooks and demonstrates how state policy in Kazakhstan seeks to preserve traditional ideas about gender roles and roots them in the national identity. Considering the authoritarian nature of the regime, existing grassroots organisations/efforts that are currently seeking to offer a comprehensive sex education that is not based on traditional gender roles will face a lack of resources and social backlash and will unable to compete with the state's gender ideology.
\end{abstract}

Keywords: sexuality education, gendered nationalism, heteronormativity

Arystanbek, Aizada. 2021. Sex Education (or the Lack Thereof) in Kazakhstan: Heteronormative Propaganda in the Curriculum of Özin Özi Tanu/Samopoznanie. Gender a výzkum / Gender and Research 22 (2): 11-27, http://dx.doi.org/10.13060/gav.2021.017.

The relationship between education and nation-building constitutes a carefully balanced act between freedom and control which modern states engage in as biopolitical institutions. Mass education is used as a tool for the state to homogenise 


\section{NV STATI / ARTICLES}

its population, especially during the nation-building process (Bandiera et al. 2019). Sex education is a direct example of how a different way of behaving in the private sphere is taught and normalised via the school curriculum that is designed and approved by the state. Sex education is often considered a tool of empowerment for younger generations to help them 'gain greater control over their lives and circumstances' (Thompson 2007: 21). According to the World Health Organization (WHO), some empirically proven benefits of sex education include the decline of teenage pregnancies and abortion, as well as a lower rate of sexually transmitted infections (STIs). Some form of sex education in the school curriculum remains mandatory in many countries, such as the Netherlands and New Zealand (Naezer, Rommes, Jansen 2017; Fitzpatrick 2018).

This study offers an investigation into how questions of sexuality and gender can be weaponised by the state to enforce a homogeneous view of the institution of family and heteronormative practices via the schooling system. The patriarchal norms that police sexual behaviour do not necessarily take the form of overt state-sponsored sex education. They can also come in the form of more covert schooling policies that promote traditional gender norms and purposefully withhold sex education from the youth. In the case of Kazakhstan, I examine how a lack of comprehensive sex education becomes its own kind of sex education policy, one that discourages open conversations about sexuality and instead shifts the focus to the 'moral' gendered values that are prescribed as an inherent feature of national identity. Sex education is not compulsory at schools in Kazakhstan. Kazakhstan's Strategy of Family and Gender Politics to 2030 envisions the wider expansion and implementation of the current course for students 'sexual and reproductive health, safe sexual behaviour, prevention of unwanted pregnancies, prevention of STI / HIV transmission' (Akorda.kz 2016: 27). However, official policies have yet to be developed and enforced in the country.

In my study, I look at the case of özin özi tanu or samopoznanie, ${ }^{1}$ a subject that students study at school that is aimed at their moral development. It does not offer official sex education but rather a set of guidelines on gender roles for young men and women. I argue that özin özi tanu positions Kazakhstani women's bodies as tools for national reproduction, with women's primarily societal role limited to preserving cultural traditions and serving as the markers between the borders of ethnic/ national groups (Yuval-Davis, Anthias 1989). Given this positionality of women under Kazakhstan's authoritarian regime, quality sex education that prioritises health and safety becomes unfeasible, as it would require policies and laws that actively advocate for gender equality, protect women's agency over their bodies and sexuality, and challenge current gendered cultural norms. Even if alternative resources are being

\footnotetext{
1 'Özin özi tanu' is the name of the subject in the Kazakh language and 'samopoznanie' is the Russian version of the name. Both directly translate as 'knowing oneself' or 'knowing yourself'.
} 
developed by grassroots movements in the country, they lack resources, reach, and support to compensate for the lack/absence of sex education in school and to compete with the state-sponsored message that enforces traditional gender norms and discourages women from learning about sexuality.

First, I outline the methodology of the study followed by a literature review. Then, I turn to providing a brief background of Kazakhstan's existing sex education policies and analyse the country's gender ideology to explain how the question of sex education is weaponised by the state. I focus on the case of özin özi tanu in the following section that examines the textbook for this subject as the primary source of this study and ties the argument back to how this school subject promotes homogeneous gender norms and heteronormative behaviour. This discussion is followed by the conclusion.

\section{Methodology}

The methodology of this qualitative study is a case study using interpretive policy and discourse analyses. The case study centres on özin özi tanu, a subject that students study at secondary schools across the country and that appears to promote heteronormative ideas of hegemonic femininity and masculinity that align with the state's gender ideology. Since özin özi tanu is part of the curriculum in many public schools across the country and its inclusion in this curriculum is allowed and sponsored by the Ministry of Education and Science of the Republic of Kazakhstan, I consider the subject a part of the state policy and therefore apply policy analysis methodology. I base my analysis on the official textbooks for özin özi tanu for high school grades 9, 10, and 11. The textbooks are available online for public access and are either directly published by the Kazakhstani government or a government agency. They are published in the Russian and Kazakh languages. For this study, I focus on the Russian version of the textbooks and use my own translation into English for quotations. These documents represent important social, cultural, and educational artefacts. By examining the language of the özin özi tanu textbooks, I draw attention to the coded gendered messages in the school curriculum that propagate patriarchal norms of femininity and masculinity. I specifically choose to focus on high school textbooks as an illustration that, given Kazakhstan's lack of comprehensive sex education policy, the inclusion of özin özi tanu in the curriculum represents an explicit choice of Kazakhstani government to disseminate texts supporting conservative cultural norms rather than foster an open conversation about youth's sexuality.

J. Browne et al. (2018) define interpretive policy analysis as a type of analysis that recognises the socially constructive nature of reality and the power of discourse in shaping that reality. As the authors describe it, this method presupposes that all 


\section{NV STATI / ARTICLES}

policy problems are historically and culturally constructed. The emphasis on social construction and questioning who is behind certain policies and ideas and who benefits from them places a particular importance on analysing discourse. According to M. Hajer (2006), discourse analysis is a 'continuous process of giving meaning to the vague and ambiguous socio-physical world by means of story lines and the subsequent structuration of experience through the various social practices' (Hajer 2006: 71). More specifically, a discourse analysis of policies gives us their socio-historical contexts, complicates the interests of stakeholders, and reveals how certain policies and actors can covertly perpetuate biases. M. Foucault (1978) was a pioneering scholar who wrote about the importance of discourse and how power dynamics affect even such private parts of our lives as sex. According to Foucault, sexuality is a product of its historical discourse, which was dominated by the powerful. In The History of Sexuality, he argues that such domains as sex and familial affairs that we think of as private are largely dominated by power relations that are multifaceted and more complex than simple acts of governing and prohibition. If we accept Foucault's statement that 'the manifold relationships of force that take shape and come into play in the machinery of production, in families, limited groups, and institutions, are the basis for wideranging effects of cleavage that run through the social body as a whole' (Foucault 1978: 94) as true, then we understand that power relations that are being perpetuated in individual groups, such as families, which are a core focus of gender-related policies in Kazakhstan, affect larger understandings of power roles in the society and vice versa.

The literature review is particularly important for this study, as it provides the theoretical framework for understanding the importance and interconnectedness of this case study with the bigger picture of sex education and patriarchal norms in Kazakhstan. In my analysis, I follow the constructivist argument that no language is inconsequential and is a product of power, which perpetuates certain narratives over others. To show how the language of özin özi tanu textbooks is connected to gendered national power dynamics, I apply the critical feminist perspective of nationalist policies.

\section{Literature review and theoretical framework}

The connection between state ideology and a set of expectations about the behaviour of its members based on their gender was first discussed by R. Connell (2005). Connell conceptualises hegemonic masculinity as 'the pattern of practice (i.e. things done, not just a set of role expectations or an identity) that allowed men's dominance over women to continue' (Connell, Messerschmidt 2005: 829). According to Connell, although only a small minority of men were assumed to possess hegemonic masculinity, it was defined as a normative concept and applied to all men 
in general. Essentially, the concept of hegemonic masculinity incorporates all the norms that make a man into the most honourable version of himself, as deemed by the society, and positions all men in relation to this standard, while also legitimising 'the global subordination of women to men' (Connell, Messerschmidt 2005: 829). M. Schippers (2007) builds upon Connell's work to arrive at the following term that I use as the main definition of hegemonic femininity in my thesis: 'Hegemonic femininity consists of the characteristics defined as womanly that establish and legitimate a hierarchical and complementary relationship to hegemonic masculinity and that, by doing so, guarantee the dominant position of men and the subordination of women.' (Schippers 2007: 94) Hegemonic femininity, therefore, surmises men in the dominant position in society and women as inferior to them. While Schippers states that most expressive features of hegemonic masculinity and femininity might be ubiquitous, their peculiarities and daily manifestation depend on the empirical context, which warrants an exploration of what standards of hegemonic femininity look like in Kazakhstan today.

Scholars who have expanded feminist critique of nationalism include N. Yuval-Davis and F. Anthias (1989), V. S. Peterson (1999), and J. Vickers (1990). Yuval-Davis and Anthias outline different ways in which women and their bodies are employed by the patriarchal state to further its nationalist agenda. These ways include designating women as transmitters of local culture, and highlighting their roles as biological reproducers, educators, and nurturers, as well as markers of national and ethnic differences between groups (Yuval-Davis, Anthias 1989: 7). Vickers describes it as 'battle of the cradle' and 'battle of the nursery' (Vickers 1990). The 'battle of the cradle' refers to the conventional ways in which women are allowed to bear children, whereas the 'battle of the nursery' is about what are deemed the culturally appropriate ways of bringing up children. According to Peterson, the 'battle of the cradle' is 'threatened by non-reproductive sex', as it lies outside women's primary role as child-bearers (Peterson 1999: 45). Thus, women are continuously placed on an invisible pedestal as mothers and wives, who transmit cultural values and traditional practices to their children and keep the nation connected to its roots. This helps us to understand the importance assigned to women's sexuality by the state and, consequently, how sex education can be a highly politicised matter with an explicit message about the importance of girls' chastity and pushback to comprehensive and critical sexuality education, which is often painted as a threat to local norms and values (Tengrinews 2020). In her book, Judith Butler (1990) also posits that gender is not a natural set of behaviours but rather an amalgamation of learned behavioural acts that forms over a given time in each culture. This is a constructivist view of gender identity that is reinforced by the existence of textbooks that teach young children what 'real' women and men are like. 


\section{NV STATI / ARTICLES}

Local context is also important for understanding the emphasis on gendered national identities and the lack of comprehensive sex education. Kazakhstan's colonial past and recent independence place the nation in a relatively more insecure position compared to older states, where the stakes of reproducing the nation may be less aggravated by shifting mentalities and developing public identities. L. Gandhi (1998) also highlights an important tendency among postcolonial societies as trying to forget their violent past and re-invent themselves on their terms (Gandhi 1998: 4), which is what Kazakhstan's government has been actively doing for the past three decades by coming up with different strategies of nation-building (Kudaibergenova 2015). The tactic of burying colonial pasts and inventing new identities is present in the way Nursultan Nazarbayev, the authoritarian leader of the country, initiated various economic and social programmes aimed at re-defining Kazakhstani identity, such as Ruhani Zhangyru and Kazakhstan 2050.2

Turning back to the literature on sex education, there have been a significant number of studies linking quality sex education to women's empowerment, the disruption of gender roles, and a mitigation of future risks of contracting STIs and engaging in sexual violence. K. M. Najmabadi and F. Sharifi (2019) have reported that some of the effects of sex education include 'more progressive attitudes toward girls and women, less agreement with hegemonic masculinity ideology, and increases in sexual health, resource knowledge, and positive attitudes of the women' (Najmadabi, Sharifi 2019: 152). R. G. Grose, S. Grabe, and D. Kohfeldt (2014) also argue that gender stereotypical behaviour and scripts of sexual behaviour are learned not only within individual familial settings but from institutions as well. The authors emphasise the potential transformative power of sex education by highlighting the constantly shifting and malleable nature of gender identities and ideologies. The social construction perspective calls for the implementation of sex education in the schooling system as a tool to socialise the younger generation into a more egalitarian and inclusive society. The authors also draw attention to the fact that 'greater sexual knowledge predicted fewer rape-supportive beliefs six months later' (Grose, Grabe, Kohfeldt 2014: 743).

Shapiro's (2001) case study of sex education in Russia echoes the argument that the state can uphold certain narratives and demonstrate consistent bias in its policies. Shapiro argues that Russian youth cannot wait much longer for an adequate sex education policy as the issue of such education has become heavily politicised and has a growing number of opponents. The politicisation of sex education in Russia

\footnotetext{
2 'Kazakhstan 2050' is a government strategy that is designed to achieve economic and social prosperity in the country by the year 2050. Ruhani Zhangyru is a separate programme dedicated to cultural development that is a part of Kazakhstan 2050. Both programmes were invented and proposed by Nazarbayev and are parts of his vision of how Kazakhstan should develop over time, which involves preserving the cultural heritage of the Kazakh nation, while having a steadily developing economy.
} 
could be of similar origin as in Kazakhstan as both countries share political history and geographical proximity. Shapiro also highlights the role of Russian religious institutions in the matter. The question of religion is also important to consider in case of Kazakhstan as well due to the rise of Kazakh Muslim identity in the past years (Yemelianova 2014). Similar to this study, M. Naeimi and J. Kjaran's (2021) study is a good example of the way the state weaponizes Muslim identity to create a heteronormative image in school's textbooks in Iran. The authors pick up on four main trends found in Iranian textbooks that promote heteronormativity, such as 'the erasure of sexual diversity, gender essentialism, martyrdom, and Westoxification' (Naeimi, Kjaran 2021: 15). The first three components are found in my primary source as well, which I discuss in the özin özi tanu section.

C. Campbell and M. Murray (2004) discuss the prerequisites of empowerment in collective well-being and physical health. Relying on key decolonial works, such as P. Freire (1968), the authors underline the fundamental role of community in building a 'collective understandings of how adverse social conditions undermine their health' (Campbell, Murray 2004: 189). Campbell and Murray, therefore, argue that 'participation in collective action in increasing the likelihood that people will act in health-enhancing ways, and in lobbying for the creation of community contexts that will enable improved health' (Campbell, Murray 2004: 189). This argument gives prominence to the need for comprehensive sexuality education that is created for the community with the needs of the said community in mind, rather than constructing a reductive top-to-bottom model of education that, according to the author, has fewer chances of succeeding at empowering the community. Robust feminist organisational efforts are needed to provide an intersectional view on the issue of sex education that considers which vulnerable groups require resources and builds a system of support rooted in inclusion and solidarity.

\section{Gender roles and Kazakhstan's sex education policies}

Kazakhstan's school curriculum does not include a separate course in sex education. An alternative offered in some schools across the country is a subject named 'valeology', the science of healthy living, which is taught in middle school. The questions of bodily anatomy related to sexuality, such as menstruation, are also covered in biology classes. Some topics related to sexuality, relationships, and gender roles also come up later in high school during özin özi tanu classes, which from Russian directly translates as 'knowledge of oneself' (Ketting, Ivanova 2018: 111). However, these subjects do not seem to have a stable place in the curriculum, as they face pushback from parents and are significantly underfunded, resulting in teachers of other disciplines having to teach them in addition to their specialty subject, as E. Ketting and O. Ivanova (2018) report. 


\section{NV STATI / ARTICLES}

For instance, the authors mention that valeology is currently not being offered in schools because of the backlash against this subject from parents and communities (Ketting, Ivanova 2018: 111). It is also worth noting that none of these subjects deal directly with questions of safe contraception, consent, and various STIs and their prevention.

The need for well-rounded sex education is evident from the fact that the average age at onset of sexual intercourse in Kazakhstan is 16.52 years (Alimbekova, Shabdenova 2018: 16). Most respondents of G. Alimbekova and A. Shabdenova's (2018) survey answered questions related to HIV and AIDS, use of condoms, and treatment of STIS incorrectly (Alimbekova, Shabdenova 2018: 34, 36, 38). Therefore, it appears that existing policies in the country do not equip young generations with knowledge in the key pillars of sex education, which highlights the need for a comprehensive sex education that would be available to all sectors of society, especially rural populations. The latter showed a much lower level of knowledge when asked questions about the issues mentioned above. Thus, the need for sex education in Kazakhstan seems quite apparent, even with the subjects of özin özi tanu and alternative sources currently being offered.

To understand why the Kazakhstani government has not yet provided comprehensive sex education in its school curriculum, we need to look not at the policies that deal directly with sex education (or the lack thereof) but at the bigger picture of what norms of hegemonic femininity and masculinity are promoted in schools. Even if there is a lack of national policy on sex education, a particular message about women's bodily autonomy, gender roles, and femininity and masculinity is still encoded in a variety of resources disseminated among school students. I argue that the state continues to propagate standards of hegemonic masculinity and femininity to younger generations while failing to provide a cohesive sex education, despite data showing that the young population in Kazakhstan is ill-equipped with information at the onset of their sexual activity. This is most evident in the case of özin özi tanu as a discipline.

The Kazakhstani government seems to have a specific image of gender roles and ideology that it propagates via different sources, which contrasts the model of developing policies and understandings collectively recommended by Campbell and Murray. If we look at the official text of the 2006-2016 Strategy for Gender Equality in Kazakhstan, the importance of national cultural values is coded in the section 'Achieving gender equality in the family. Strengthening of the family and an increase of parenting in the family'. While the strategy outlines key aspects of national culture in need of critical examination and modification, some parts of it remain reductive about what constitutes gender equality and women empowerment. For instance, the section on gender equality in the family focuses extensively on high divorce rates, the increase in the number of single men and women, and the tendency to not have more than one child. At the same time, the document brushes past the patriarchal power 
structures of the family by stating that there has been an 'actual reformation' of these structures without providing any quantitative or empirical evidence in support of this claim. While high divorce rates and low birth rates constitute areas for legitimate concern, the classification of these issues in the document as the main 'threats' for achieving gender equality within the family does not seem particularly germane to the cause. Outlining these 'threats' and ignoring the recognition of other issues such as the unequal division of household work, marital rape, and domestic abuse paints a picture that the government of Kazakhstan is mostly concerned with preserving families for the sake of the nation. A proper examination of the high rate of divorce and share of single people in Kazakhstan today would require analysing why Kazakhstani women are willing nowadays to choose divorce or a single life, as these could be symptomatic of a larger problem of a power imbalance within families.

The importance of the preservation of the specifically Kazakh national tradition in the family for the government is further evident in the strategy's tasks of the revival of 'moral values and the cultivation of a positive image of family and marriage' and the revival of 'the best familial, ethnocultural traditions that contribute to the strengthening of spiritual and moral foundations of marriage and family'. 'Moral values' and 'ethnocultural traditions' confirm the supremacy of specific ethnic traditions and norms that are being endorsed by the government as essential features of functional families in Kazakhstan. This insinuates that Kazakh ethnic traditions are to be preserved and protected in their original form, whatever that might be. The insistence on preserving ethnic traditions and the moral standards of family in the gender equality strategy reinforces the state's rhetoric that indelibly associates women with family issues. All this adds up to a message from the state about the pre-eminence of the family that tethers women to certain ideas of femininity that claim to be inherent to Kazakh culture.

\section{The case of özin özi tanu}

A prime example of how this message is being transmitted to the youth in the country is the content of textbooks used in özin özi tanu classes. While özin özi tanu could be interpreted as a certain variant of sex education, a deeper look into the discipline highlights its clear agenda and the worrisome idea of morally 'right' kinds of femininity and masculinity, which contradicts sex education's principle of empowerment. In particular, the subject's textbook represents a problematic conceptualisation of femininity and masculinity. School textbooks are used as a tool to promote heteronormativity and heterosexism by excluding undesirable identities, assuming heterosexuality as the norm, and passing judgement on behaviours that diverge from the norm (Wilmot, Naidoo 2014). Özin özi tanu is an existing subject 


\section{NV STATI / ARTICLES}

in the country's school curriculum that had the potential to compensate for the lack of sex education appears, on the contrary, to steer the conversation away from safety and agency to the moral obligations young people have towards their future family and, most importantly, towards their nation. The lessons of özin özi tanu are then ultimately tied back to the idea of preserving traditional family values outlined in the Strategy for Gender Equality.

The özin özi tanu ninth-grade textbook has two chapters on gender roles: one titled 'Women's Destiny' and another titled 'Man as the Embodiment of Duty, Responsibility, and Discipline' (Kalacheva et al. 2019). The first chapter poses a question of whether femininity is needed before promptly arguing in favour of a certain standard of femininity, while stating that unfemininity, on the other hand, is multifaceted. According to the textbook, gender equality does not mean gender similarity and that women who choose to engage in traditionally masculine behaviours such as smoking, making inappropriate jokes, and being rude eventually face the threat of being viewed as 'one of the boys.' Femininity, on the other hand, is defined by a woman's ability to be sensitive and understanding towards others, as well as by a woman's need for 'emotional connection'. This illustrates Naeimi and Kjaran's argument of how heteronormativity is fostered via gender essentialism. The textbook sends a message that there are only two genders and that they both should be strictly guided by traditional ideas of femininity and masculinity.

The ninth-grade textbook juxtaposes the sensibility and malleability of women with the decisiveness and strength of men while condemning any deviation from these modes of behaviour. What is at stake here, according to the textbook, is a woman's ability to keep a husband and build a happy family in the heteronormative sense of the concept. 'It is an unwritten obligation, a moral duty of a young woman, to be feminine! To be feminine so that a man can be masculine.' (Kalacheva et al. 2019: 61) According to the authors, guiding men through the relationship with grace, tact, and finesse is a skill available only to feminine women. This is a form of martyrdom, another element of heteronormative propaganda, according to Naeimi and Kjaran. Women are instructed to remain in the subordinate position of serving their male partners. Furthermore, the chapter on fatherhood also argues that the role of the mother remains the primary one in any family, while normalising a certain distance between fathers and their children. 'Maybe it should be this way with the mother on the frontline? Because it is the mother who is the natural nurturer of her children.' (Kalacheva et al. 2019: 76) The textbook for eleventh-graders has a similar message. When discussing a woman's destiny, the book states that it is 'about being a caring and loving mother, transmitting moral values to her children, and preserving peace and harmony withing the family' (Omarova et al. 2020: 84). The book advises young women to make a choice between 'career, wealth, pleasures' and 'creating a happy 
family' (Omarova et al. 2020: 84), implying that the morally right choice would be the latter. This way both textbooks seek not only to establish the unquestionable nature of the woman's role in the 'battle of the nursery' but also to reassure their young audience that fatherhood is important for the man's masculinity but, unlike when it comes to motherhood, its terms are open to negotiation and interpretation. Finally, the textbooks also completely ignore any other sexuality except heterosexuality, marking another principal discourse of heteronormativity pinpointed by Naeimi and Kjaran. Thus, the textbooks teach the students the dichotomy of masculinity and femininity based on strictly heterosexist understandings, which essentially tether a woman's value to her ability to find and keep a man and nurture children. This is a part of the gendered nationalist rhetoric outlined by Yuval-Davis and Anthias and others.

The strengthening of the family outlined in the Gender Equality Strategy is also reflected in the eleventh-grade textbook, which states: 'Serving family is the main aim in life. The goal of servitude is to overcome your desires and give happiness and positive energy to those around us.' (Omarova et al. 2020: 96). The tenth-grade textbook directly comments on the 'change' in family values in modern society. The book condemns civil unions as a degradation of familial responsibilities. 'The attitude toward family values has changed. Living in civil union has become normal. [...] The notion of familial responsibility is being reconsidered. The once steady, unextinguishable family hearth no longer exists. You are living together, you do not like something, you leave' (Galiyeva, Lekanova 2019: 42). This overt prioritisation of family and heterosexual monogamous marriage may not appear relevant to the matter of sexuality education. However, it does contribute to the normalisation of only specific type of relationship and stigmatises choices that lie outside that kind of relationship, and this may deter young people from asking questions and exploring their own identities and desires. In the context of a patriarchal society, the duty to family and the emphasis on legal marriage over civil unions imply that being sexually active of marriage is to be a breaking some rule. This might not deter teenagers from being sexually active, but it might amplify the stigma and shame around sexual activities and contribute to a poor level of knowledge about sex. The language of servitude and putting duty over desire is followed by a clear-cut gendered division of those duties when a man is described as the head of the family, while the woman's role as the transmitter of cultural values is highlighted. According to Peterson, this cements the hierarchy of gendered behaviours that then leads to the normalisation of violence against those members of society that stray from the norm.

As a discipline, özin özi tanu aims to act as a comprehensive guideline to behaviour that is defined as morally 'correct.' Words such as 'purity, spirituality, and unity with nature' (Domnin 2010) were used by one school principal to describe the values propagated by the subject. The use of these particular words is significant, as it 


\section{STATI / ARTICLES}

connects spirituality with 'purity' and naturalises the teachings of the subject as the norm. This could be seen as exacerbating the stigma around sex and women's sexuality, as well as perpetuating a didactic mode of teaching about sexuality, as opposed to engaging young girls and boys in discovering and interpreting sexual identities and gender roles. In 2018, by Order No. 522 of the Minister of Education and Science of the Republic of Kazakhstan the curriculum of özin özi tanu was granted approval to be taught in schools across the country. The curriculum that was approved includes several potentially worrisome points, such as calling the 'principle of national heritage' a key pillar of the discipline. According to this Order, özin özi tanu teaches students 'knowledge of universal values through the prism of national culture' (Ministry of Education and Science of the Republic of Kazakhstan 2018). The end goal, according to this Order, includes students readily displaying civility and patriotism. The government has thereby established a firm connection between a subject taught in school that is supposedly aimed at the moral development of youth and national identity, which is rooted in morally correct behaviour and that filters all values through the perspective of national culture. Knowing oneself is equated with knowing one's place within the nation, which, if we look at the content of the textbook, is based on standards of hegemonic femininity and masculinity. The language of all three textbooks not only prioritises family in everyone's life but also specifically names national traditions as a central component of a family (Galiyeva, Lekanova: 93).

It is also important to note that the author of özin özi tanu as a discipline is Sara Nazarbayeva, the wife of the first president and long-term dictator Nursultan Nazarbayev. She first introduced the subject in 2001. On the official website of özin özi tanu, it is described as a form of moral and spiritual training and education, its mission being to provide 'pedagogical support to students in the process of their personal development and socialisation on the basis of universal values, the traditions of his nation, and world culture' (Ozin-ozi-tanu.kz 2021). The discipline positions itself as a moral guide, which implies that its teachings are there to prevent the younger generation from an immoral way of living. From the content of the textbooks, this morality is rooted in hegemonic standards of femininity and masculinity. There is a clear connection between nationalist values and notions of morality, whereby the morality standards rooted in hegemonic femininity and masculinity that are propagated in özin özi tanu become linked to nationalistic sentiments. The mission, for instance, explicitly states the importance of national traditions in young people's upbringing.

The coded language of the textbooks discussed above do not provide any direct instructions on how men and women should behave when it comes to sexuality, nor is any such information contained in the özin özi tanu's mission statement or its 2018 curriculum. However, by preaching certain norms of respectable behaviour, 
such as women having to be feminine and dedicated to their families, not only does özin özi tanu establishes a stigma around women's sexuality and challenges the idea that women can mould their femininity, it also suggests that femininity itself is a one-dimensional concept. The textbook swiftly puts women on a pedestal for the emotional labour they must take on in heterosexual relationships, while also encouraging men to appreciate that labour and be more present. All of this not only excludes non-heterosexual and non-monogamous identities and relationships, which contributes to the stigmatisation of the LGBTQ+ community in Kazakhstan, it also cements the woman's role as the carrier of culture and biological reproducer, as the book clearly highlights her 'destiny' to be a mother and a wife above all else.

Considering that the credit for introducing and developing the özin özi tanu is mostly assigned to a single person, Sara Nazarbayev, who is backed by the extreme political power of her spouse, the message of morally appropriate and respectable behaviour clearly aligns with state ideology. Özin özi tanu, thus, is a part of the cultural hegemony in Kazakhstani society. This traditional ideology that the subject promotes leads young people to continue adopting 'traditionally gendered norms and sexual scripts in their own behaviour' (Gross, Grabe, Kohfeldt 2014: 750). Without challenging traditional gender roles and questioning the power structures that promote the cultural hegemony of heteronormativity, the social issues surrounding sexuality, such as awareness about HIV, STIs, consent, contraception, and stigmatization of non-heterosexual behaviour, will not be addressed. Thus, the methods and the content propagated by özin özi tanu seem to undermine its very mission of student development and empowerment, as it instead continues to trap them within narrow traditional views of femininity and masculinity.

\section{Conclusion}

This study demonstrates how the promotion of heteronormative patriarchal values within the schooling system can occur outside of what is traditionally considered to be sex education. The Kazakhstani government promotes normative gender roles and standards of hegemonic femininity and masculinity by introducing such a subject as özin özi tanu, which promotes rigid understandings of morally 'correct' behaviour for women and men in relationships and gender performance. By focusing on the case of özin özi tanu in Kazakhstan, I argue that the state's lack of any comprehensive sex education programme and the existence of subjects that propagate traditional gender roles constitutes a covert sexuality policy that tethers 'morally correct' sexual behaviour to national identity. The discourse analysis of three recent özin özi tanu textbooks reveals continuous emphasis on national traditions and family values rooted in gender roles. By equating femininity with passivity, sensibility, obedience, and malleability, 


\section{STATI / ARTICLES}

özin özi tanu assigns a woman's value to her ability to find a husband and preserve their relationship within the institution of heterosexual monogamy with biological reproduction seen as the main goal. Much in the way that gender equality is discussed in the context of family planning in the official gender equality strategy document, relationships are discussed only in the context of heterosexual marriage in the özin özi tanu curriculum. The emphasis on hegemonic femininity produces the implicit message that a woman's value lies in her ability to maintain a marriage and pass on cultural values to the next generation. The özin özi tanu textbook does not offer any alternatives to the 'moral development' of youth, while young people's rejection of traditional gender roles and the topic of sex in general are not considered worthy of analysis. All this reinforces the stigma attached to any deviation from gender norms, especially when it comes to sexual activity. The main contribution of this study is that it showcases even if a state does not have an official sex education policy, it is still trying to promote patriarchal values through the schooling system which results in conditions conducive to irresponsible sexual behaviour among young people. This study suggests a more insightful approach to researching sex education policies in different communities that goes beyond the official curriculum and policies directly related to sexuality and draws attention to the way this topic could implicitly be addressed by other school subjects. Even in the climate of enforced heteronormativity, a comprehensive sex education policy is essential, especially in the light of recent surveys demonstrating how little knowledge young people have about such issues as STIS, HIV, and contraception.

Özin özi tanu has the potential to be a viable alternative to sex education classes in Kazakhstan, as it could be a safe space for students to openly discuss and question social norms and issues, including those related to sexuality and gender ideology. Even without dealing with questions of sex openly, a discipline that claims to support children in their journey towards becoming responsible adults and members of society could embrace the model of comprehensive empowerment and recognise a plurality of sexual behaviours, expressions, and identifications. However, the curriculum that came into effect in 2018 demonstrates that the discipline appears to favour a myopic vision of who its students should be when they grow up, and this vision is strongly based on the country's national culture. The need for comprehensive sex education and for alternative sources of information on this subject has been noticed by several organisations in the country, which have taken it upon themselves to offer this information. As early as 1996, the Kazakhstani Association of Sexuality and Reproductive Health (KMPA), a volunteer non-profit organisation, was created. Its mission is to improve the quality of sex education in the country. In 2018, an educational website for Kazakhstani teenagers and their parents called Uyat Emes was created. A grassroots organisation that is not supported by the government, Uyat Emes offers online resources, as well as in-person lectures and workshops with students, teachers, 
and parents to improve the quality of sex education in the country and fight against the pushback from the communities against said education. Another organisation that offers professional training and free consultations for youth is Ne Tabu. All these and other organisations are helping to educate youth and other groups about both sexuality and gender roles and norms. Their existence is proof of the continued need for such organisations in Kazakhstan. However, NGOs that do not work with the government on developing policies, textbooks, and curricula remain largely alienated from most of the population and lack resources and political power to extend their services on a regular basis to every school. Considering the authoritarian nature of the Kazakhstani regime, any systemic change would require backing from the government to get access to its target audience, obtain financial support, and effectively deal with the imminent pushback from communities. While Kazakhstan's power elites continue to promote heteronormativity in their projects aimed at the 'moral' education of youth, an example of which is özin özi tanu, any alternative grassroots organisations are likely to experience significant difficulties in their educational work to be able to engender a substantial shift in society's consciousness.

\section{References}

Alimbekova, G., A. Shabdenova. 2018. Социологическое Исследование По Изучению Состояния Репродуктивного Здоровья Подростков и Молодых Людей 15-19 Лет, Их Сексуального Поведения и Доступа к Услугам и Информации в Области Охраны Репродуктивного Здоровья. Ministry of Health care of Republic of Kazakhstan. Retrieved 4/1/2021 (https://kazakhstan.unfpa.org/sites/ default/files/pub-pdf/\%D0\%9E\%D1\%82\%D1\%87\%D0\%B5\%D1\%82\%20 \%D1\%80\%D1\%83\%D1\%81._2.pdf).

Akorda. 2005. Стратегия Гендерного Равенства В Республике Казахстан На 2006-2016 Годы. Akorda. Retrieved 14/12/2020 (http://www.akorda.kz/upload/nac_komissiya_po_delam_ zhenshin/5.2\%20\%D0\%A1\%D0\%93\%D0\%A0\%20\%D1\%80\%D1\%83\%D1\%81.pdf).

Browne, J., B. Coffey, K. Cook, S. Meiklejohn, C. Palermo. 2018. A Guide to Policy Analysis as a Research Method. Health Promotion International 34 (August): 1-13. https://doi.org/10.1093/heapro/day052

Campbell, C., M. Murray. 2004. Community Health Psychology: Promoting Analysis and Action for Social Change. Journal of Health Psychology 9 (2): 187-95, https://doi. org/10.1177/1359105304040886.

Connell, R. W., J. W. Messerschmidt. 2005. Hegemonic Masculinity: Rethinking the Concept. Gender \& Society 19 (6): 829-59, https://doi.org/10.1177/0891243205278639.

Domnin, S. 2010. Курс 'Самопознание' Должен Стать Основой Духовно-Нравственного Воспитания Молодежи. Zakon.Kz, March 2. Retrieved 2/2/2021 (https://www.zakon. kz/164684-kurs-samopoznanie-dolzhen-stat-osnovojj.html). 


\section{NV STATI/ ARTICLES}

Facebook. 2020. Data Policy. Facebook. Retrieved 19/11/2020 (https://www.facebook.com/ policy.php).

Fitzpatrick, K. 2018. Sexuality Education in New Zealand: A Policy for Social Justice? Sex Education 18: 1-9, https://doi.org/10.1080/14681811.2018.1446824.

Foucault, M. 1990. Part IV, The Deployment of Sexuality. Chapter 3 Domain, Pp. 103-114 in History of Sexuality. New York: Vintage Books.

Gandhi, L. 1998. Introduction. Pp. 1-22 in Gandhi, L. (ed.) Postcolonial Theory: A Critical Introduction. New York: Columbia University Press.

Kalacheva, I., G. Kaliyeva, T. Lekanova. 2019. Самопознание. Учебник для 9 класса. Almaty: Böbek.

Kalieyva, G. I., T. Lekanova. 2019. Самопознание. Учебник для 10 класса. Almaty: Böbek.

Ketting, E., O. Ivanova. 2018. Sexuality Education in Europe and Central Asia: State of the Art and Recent Developments. Cologne: Federal Centre for Health Education (BZgA). Retrieved 4/4/ 2021 (https://www.ippfen.org/sites/ippfen/files/2018-05/ Comprehensive\%20Country\%20Report\%20on\%20CSE\%20in\%20Europe\%20and\%20 Central\%20Asia_0.pdf).

Kudaibergenova, D. T. 2015. The Ideology of Development and Legitimation: Beyond 'Kazakhstan 2030'. Central Asian Survey 34 (4): 440-55, https://doi.org/10.1080/026349 37.2015.1115275.

Ministry of Education and Science of the Republic of Kazakhstan. 2018. Об утверждении программы нравственно-духовного образования 'Самопознание' (изменения на 29 сентября 2018). Ministry of Education and Science of the Republic of Kazakhstan. Retrieved 2/22021 (https://tengrinews.kz/zakon/pravitelstvo-respubliki-kazahstanpremer-ministr-rk/obpazovanie/id-V1800017623/).

Ministry of Justice of the Republic of Kazakhstan. 1995. Constitution of the Republic of Kazakhstan. Astana: Ministry of Justice of the Republic of Kazakhstan. Retrieved 19/11/2020 (http://adilet.zan.kz/rus/docs/K950001000_).

Mosse, G. L. 1988. Nationalism and Sexuality: Middle-Class Morality and Sexual Norms in Modern Europe. Madison, Wl: University of Wisconsin Press.

Murthy, D. 2008. Digital Ethnography: An Examination of the Use of New Technologies for Social Research. Sociology 42 (5): 837-55, https://doi.org/10.1177/0038038508094565.

Musabekova, А. 2021. Халида Ажигулова, Юрист: «Законы Не Должны Приниматься в Интересах Привилегированного Меньшинства». Vlast.Kz. February 2. Retrieved 2/2/2021 (https://vlast.kz/gylymfaces/43619-halida-azigulova-urist-zakony-ne-dolzny-prinimatsa-vinteresah-privilegirovannogo-mensinstva.html).

Naeimi, M., J. Ingvar Kjaran. 2021. Schooling (Hetero)Normative Practices in the Islamic Republic of Iran. Sex Education:1-17. https://doi.org/10.1080/14681811.2021.1911797.

Omarova, G. A., A. K. Rysbayeva, E. M. Loseva, A. B. Saparbayeva. 2020. Самопознание. Учебник Для 11 Класса. Almaty: Böbek.

Ozin Ozi Tanu. n.d. Миссия Проекта. Retrieved 14/1/2021 (http://ozin-ozi-tanu.kz/).

Peterson, V. S. 1999. Sexing Political Identities/Nationalism as Heterosexism. International Feminist Journal of Politics 1 (1): 34-65, https://doi.org/10.4324/9780203361122_ chapter_4. 
Shapiro, B. Y. 2001. School-Based Sex Education in Russia: The Current Reality and Prospects. Sex Education 1 (1): 87-96, https://doi.org/10.1080/14681810120041742. Schippers, M. 2007. Recovering the Feminine Other: Masculinity, Femininity, and Gender Hegemony. Theory and Society 36 (1): 85-102, https://doi.org/10.1007/s11186-0079022-4.

Tengrinews. 2020. 'Сексуальное Образование - Это Не Обучение Техникам Секса'. Как Обезопасить Детей От Насилия. Tengrinews, July 30. Retrieved 14/1/2021 (https:// tengrinews.kz/article/seksualnoe-obrazovanie-ne-obuchenie-tehnikam-seksa-1473/).

Tengrinews. 2018. Законы - Об утверждении программы нравственно-духовного образования 'Самопознание' (изменения на 29 сентября 2018) V1800017623 I Tengrinews. kz. Главные новости Казахстана - Tengrinews.kz. Retrieved 10/2/2021 (https://tengrinews. kz/zakon/pravitelstvo-respubliki-kazahstan-premer-ministr-rk/obpazovanie/idV1800017623/).

United Nations Population Fund (UNFPA). 2014. UNFPA Operational Guidance for Comprehensive Sexuality Education. New York: United Nations Population Fund. Retrieved 4/1/2021 (https://www.unfpa.org/sites/default/files/pub-pdf/UNFPA_ OperationalGuidance_WEB3.pdf).

United Nations Treaty Collection. 1981. Convention on the Elimination of All Forms of Discrimination against Women. New York: United Nations Treaty Collection. Retrieved November 19, 2020 (https://treaties.un.org/Pages/ViewDetails.aspx?src=IND\&mtdsg_ no=IV-8\&chapter=4\&clang=_en).

Vickers, J. M. 1990. At His Mother's Knee: Sex/Gender and the Construction of National Identities'. Pp. 478-92 in Hoffmann Nemiroff, G. (ed.). Women and Men: Interdisciplinary Readings on Gender. Toronto: Fitzhenry \& Whiteside.

Wilmot, M., D. Naidoo. 2014. 'Keeping Things Straight': The Representation of Sexualities in Life Orientation Textbooks. Sex Education 14 (3): 323-337, https://doi.org/10.1080/146 81811.2014.896252.

Yemelianova, G.M. 2014. Islam, National Identity and Politics in Contemporary Kazakhstan. Asian Ethnicity 15 (3): 286-301. https://doi.org/10.1080/14631369.2013.847643.

Yuval-Davis, N. 2003. Nationalist Projects and Gender Relations. Narodna UmjetnostHrvatski Časopis Za Etnologiju i Folkloristiku 40 (1): 9-36.

Yuval-Davis, N., F. Anthias. 1989. Women-Nation-State. New York: St. Martin's Press.

(c) BY-NC Aizada Arystanbek, 2021.

(c) BY-NC Institute of Sociology of the Czech Academy of Sciences, 2021.

Aizada Arystanbek is a sociologist and gender studies expert whose research interests draw extensively on ethnographic methods and are centred on gender, culture, decoloniality, and nationalism. She is particularly interested in the issue of violence against women in relation to state policy. She obtained her master's degree in gender studies from the Central European University, Hungary, and the University of Oviedo, Spain. She is currently working towards her PhD in sociology at Rutgers University, New Jersey. Contact e-mail: a.arystanbek@rutgers.edu. 